\title{
Reforms of Local Finance and Taxation in Hungary. Milestones and Junctions Since 1990
}

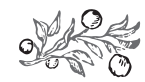

\section{Summary}

The current system of Hungarian local finance and taxation has evolved through consecutive changes since 1990. Among the many amendments to the underlying law, a couple of milestones and junctions should be pointed out. The signature of the European Charter of Local-Self Government in 1994 had symbolic importance. The comprehensive reform after 2010 was the biggest milestone without a doubt, because a new constitution and a new act on local governments were adopted by Parliament. Furthermore, it was also decisive that the central government bailed out local governments. Three different models of confining local borrowing have been applied so far. The market-reliance model was replaced by passive control in 1996. Active control came into force in 2012. A closed-list approach of local taxation was applied until 2015, when the open/-list model was introduced. Even though reforms have been put in place, local business tax still prevails in the Hungarian system of local taxation, as roughly 80 per cent of all local tax revenues come from this fiscal levy. Counties were assigned power to impose local taxes in 2020 as a result of the coronavirus legislation. Before this reform only local governments had been authorised by law to impose local taxes.

Journal of Economic Literature (JEL) codes: P35, H11, H71, H74

Keywords: local finance, local taxation, local business tax, local borrowing

Dr GÁBor Kecsố PhD, lecturer, Faculty of Law, Eötvös Loránd University, Budapest (kecsogabor@ajk.elte.hu). 
Civic Review · Vol. 16, Special Issue, 2020

\section{INTRODUCTION}

This paper intends to review the development of legal arrangements in certain fields of local finance in Hungary since 1990. Milestones and junctions are discussed without going into details. To keep the length reasonable, our focus is especially on the changes of models in local taxation. In addition, the confinement of local borrowing in Hungary is also analysed.

\section{THE STRUCTURE OF HUNGARIAN LOGAL GOVERNMENTS}

Hungary has two layers of democratically elected governments: the central and the local. The local government layer consists of two tiers. There are 3178 municipalities - including Budapest - at the bottom level. Nineteen counties plus Budapest operate at the intermediate level (HCSO, 2019). The capital city represents in both tiers, because it is treated by law as a municipality and as a county at the same time. ${ }^{1}$ The feature of the Hungarian local governmental system is the spatial fragmentation of inhabitants into small(er) communities with moderate degree of decentralisation. This was a result of a comprehensive reform after 2010. How has this system evolved? This can be described from the aspect of local finance in a nutshell as follows.

The system of Hungarian local governments did not evolve in a natural and coherent way over centuries, due to changes in political, social and economic regimes. Socialist law intended to unify power (Verebélyi, 1987). Its prototype local governments called councils were not empowered to exercise autonomy in its the genuine sense of the word. ${ }^{2}$ They were treated as the local arms of the central power. This came to an end when the Soviet empire collapsed.

\section{Years of peaceful transition: Change from socialism to capitalism}

The last fundamental reform happened in Hungary in 1989-1990, when the socialist system failed, and capitalism set out on its journey. This was the beginning for local democracy. What did it really mean for localism in Hungary? It was said at that time that the elementary school for Western democracy is the field as close to people as possible. These included villages, towns and cities, all assigned the same rights, but different public duties. It was believed that independent and sovereign Hungary could be built upon autonomous municipalities according to the theory of subsidiarity (Kulcsár, 1997). That is why many public services to people (e.g. basic health care, elementary schools) and with respect to property (public lighting, cemetery, water and sewerage) were allocated to municipalities. Counties were considered as a less important level of government, and consequently they were only authorised to provide a few public services, among them secondary educational institutions and hospitals. Act LXV of 1990 on Local Governments (hereinafter referred as LGA 1990) was adopted by Parliament on the basis of this concept. The fundamental rights of local governments ${ }^{3}$ were protected by the Hungarian Constitutional Court. Its decisions 
Gábor Kecsô: Reforms of Local Finance and Taxation in Hungary. Milestones and...

construed the essential competencies of local governments against intervention by the central legislative and executive branches (Csúrös, 2006).

The 1994 signature of the European Charter of Local-Self Government (hereinafter referred to as Charter) was a hallmark in democratic development. According to the preamble of the Charter the local authorities are one of the main foundations of any democratic regime and the existence of local authorities with real responsibilities can provide an administration which is both effective and close to the citizen. Hungary ratified all the articles of the Charter including Article 9 on Financial resources of local authorities in 1997 (see Act XV of 1997 on the Charter). In sum, the priority was to make local autonomy possible in contrast to the previous decades. Scale economies and other factors of efficient public service provision were emphasised less.

Transition was, however, challenging to the Hungarian society and economy. Public budget was not an exception to this rule. The sovereign debt-to-GDP ratio increased quickly due to the large budget deficit. An austerity package was adopted by Parliament in 1995 (Lentner, 2020). In connection with this package the concept how to limit local borrowings changed. Until the end of 1995 market discipline model was applied by the LGA 1990. In this case local governments were legally entitled to borrow in the financial market without any special public law restrictions. ${ }^{4}$ The mechanisms of the financial market pose the limit in this model. The invisible hand of the newborn Hungarian financial market would provide for the "discipline" rules. Local governments could take out as much loan as seemed prudent for them and for the creditors. This liberal model was inappropriate in the practice because of market failures. The legislator shifted the model of local borrowing in 1996. The so-called rules-based approach was introduced. The borrowing capacity of local governments was capped by public law. The maximum amount of the capital and interest of the local loan was 70 per cent of the current revenues. ${ }^{5}$ On the top of that, a bankruptcy code for local governments (Act XXV of 1996) was enacted and imposed strict constraints on local governments. ${ }^{6}$ The central government was unwilling to bail them out in the case of local debt crises. The central budget was not made liable for local government liabilities. ${ }^{7}$

The long period between 2002-2010 was the era of political fragmentation between the central and local governments. The leftist-liberal parties retained their majority in the general Parliamentary election in spring 2006. The deepest fragmentation came into existence after a secret political speech was leaked to the public. As a result, the opposition political forces at Parliament scored a smashing victory in the election of local representatives and mayors in fall 2006. The effect of the US stock market crash in 2008 reached Hungarian households in a vulnerable situation. The sum of local debt was outstanding by 2010 and some local governments were threatened by insolvency.

A new beginning after 2010

The political tension between the central and local governments ceased to exist as the conservative parties won the national and local elections in 2010. They obtained more than two-thirds of the seats in Hungarian Parliament, won in all counties and 
there were only a few municipalities where they were beaten by the previous governing parties. A comprehensive legal reform was launched with great impact on the laws of local governments.

First and foremost, a new constitution, called the Fundamental Law of Hungary, was adopted. Nevertheless, its provisions on local governments are not entirely new. Many of the rules are the same or almost the same as before (Patyi, 2015). Article 32 (1) of the Fundamental Law provides - among many others - that within the framework of the statute, in the administration of local affairs, the local government:

- must establish its own budget and, based on that, must manage local government revenues independently,

- must decide on the types and rates of local taxes. ${ }^{8}$

These two provisions had also been laid down in the old constitution.

What was new in the Fundamental Law in respect of local governments was that it stipulated that: "In order to preserve a balanced budget, an Act may provide that, for any borrowing or for other undertaking of commitments by local governments to the extent determined in an Act, certain conditions and the consent of the Government shall be required" (Fundamental Law Article 34 (5)). Parliament decided to bail out local governments after the election of 2010 (Lentner, 2014), and introduced the so-called active control based on the previous constitutional mandate. As a general rule, the central government's prior approval of local borrowing is required. The conditions of the approval are specified in a statute (Act CXCIV of 2011). ${ }^{9}$ There are certain exceptions to active control: the central government's consent is not required for taking short-term loans (mature within the calendar year) and small loans (sum not exceeding certain thresholds).

Parliament adopted Act CLXXXIX of 2011 on the Local Governments of Hungary (hereinafter referred as LGA 2011). In its preamble it is pointed out that the goal of the legislator is to ensure the self-government rights proclaimed in the Fundamental Law, to create the conditions necessary for local self-government, to strengthen national co-operation, to help the self-sustaining capability of settled communities as well as to strengthen the self-supporting capability of local communities with respect to the principles set forth in the Charter.

The LGA 2011 provides the basic rules of local budgeting. The budget of local governments is part of public finances. Local budgets are separated from the central budget, but they are linked to it by intergovernmental grants and by other fiscal arrangements. The revenues and expenditures of local governments are regulated in the budget decree adopted by the local representative body. The current budget balance must not show a deficit. This provision is commonly known as the golden rule (Dafflon, 2002). According to this concept, local governments are not allowed to take out a loan to finance current expenditures (except for short-term loans repaid within a year). The outcome of the golden rule is that the current budget has to be balanced without long-term loans.

The legislator launched a large public administration reform programme in 2011 (Magyary Plan). This aimed at increasing the overall efficiency of the entire public- 
Gábor Kecsô: Reforms of Local Finance and Taxation in Hungary. Milestones and...

administrative system throughout modernizing its tasks, personnel, processes and structure. These structural reforms can be labelled primarily as centralisation, with the ambition of saving costs and having a firm control on policy processes. The reform shifted many public services - e.g. mentioned above as elementary and secondary schools, hospitals - from local governments to central government (Gellén, 2014, p. 61). Two key indicators represent the outcome of the reform. In 2010 all local expenditures amounted to 12.5 in per cent of GDP and 19.5 in per cent of general government expenditures. In 2014 all local expenditures were 8.2 in per cent of GDP and 13.2 in per cent of general government expenditures. ${ }^{10}$

\section{THE LOCAL TAX SYSTEM}

\section{The framework of local finances}

In theory, local governments can be financed in two different ways. They may have transferred resources that are given to them by other layers of government (e.g. regional, central or even EU). Intergovernmental grants belong to this group. Furthermore, they may have resources on their own rights, such as local taxes that are theoretically the most important revenue in the local budget, because these serve the fiscal autonomy at the highest degree. Local tax is a tax imposed at least at the rate decided by the local government. This definition is in line with Article 9 (3) of the Charter, which stipulates that at least part of the financial resources of local authorities must derive from local taxes and charges of which, within the limits of statute, they have the power to determine the rate. Classification of shared taxes is at issue (see Council of Europe, 2006) but I think these taxes are transferred resources as their legal structure (taxpayer, base, rate, credit, exemption) is out of the decision of local governments. Central legislative body has competence to regulate shared taxes (Kecsô, 2016).

In the Hungarian valid and applicable law, LGA 2011 replaced the old financial framework. The new "task financing system" of local governments is in effect now. Within the framework of this system, in the manner determined in the act on the annual central budget, Parliament must ensure conditional grants to cover mandatory local tasks and may ensure conditional or unconditional grants to cover other types of tasks. Three criteria should be taken into account when providing these grants: 1) economical public management 2) expected own revenues 3) actual own revenues of the local governments. Expected own revenues are applied so that local governments have sufficient interest to boost their own revenues (LGA 2011 Section 117).

In the Hungarian framework of local finances, there are some important additional sources in addition to intergovernmental grants. In 2019, the budget balance was outstanding. In order to represent a fair view, this source is not included to all local revenues in Table 1. 
Civic Review · Vol. 16, Special Issue, 2020

Table 1: The framework of local finances in 2019

\begin{tabular}{l|c|c}
\hline \multicolumn{1}{c|}{ Sources of revenues } & Sum (million HUF) & Ratio \\
\hline Local taxes & $971,489.20$ & 29.73 \\
\hline Other revenues & $399,843.20$ & 12.24 \\
\hline $\begin{array}{l}\text { Intergovernmental grants from the central government, } \\
\text { social security funds, special budget funds and the EU }\end{array}$ & $1,676,471.80$ & 51.30 \\
\hline Shared taxes & $33,753.40$ & 1.03 \\
\hline Debt instruments & $186,368.30$ & 5.70 \\
\hline $\begin{array}{l}\text { All local revenues (excluding the budget balance } \\
\text { remaining from 2018) }\end{array}$ & $3,267,925.90$ & $100 \%$ \\
\hline Budget balance remaining from 2018 & $1,461,331.70$ & \\
\hline
\end{tabular}

Source: Act CXVII of 2020 on the Implementation of the 2019 Budget 2019 Hungary

As Table 1 shows transfer dependency of the Hungarian local governments was around 50 per cent. Shared taxes were not significant in 2019 and these sources became even less important in 2020, because COVID legislation ceased to share the motor vehicle tax. This has been transformed into a fully central tax. The one and only shared tax in Hungary in 2020 is the personal income tax on the leasehold fee of agricultural land. This provides insignificant revenue for local governments.

Local taxes, however, are of paramount importance since they cover almost onethird of the local revenues. This ratio is quite stable recently, so it can be seen as a representative data. Table 2 sets out the distribution of revenues deriving from the six local taxes in 2019.

Table 2: Revenues from local taxes in 2019

\begin{tabular}{l|c|c}
\hline \multicolumn{1}{c|}{ Local (own) taxes } & Sum (million HUF) & Ratio \\
\hline Building tax & $127,594.10$ & 13.13 \\
\hline Plot tax & $24,094.70$ & 2.48 \\
\hline Communal tax & $14,566.50$ & 1.50 \\
\hline Local business tax & $788,308.40$ & 81.14 \\
\hline Tourism tax & $16,248.60$ & 1.67 \\
\hline Municipal tax & 676.9 & 0.07 \\
\hline All local taxes & $971,489.20$ & $100 \%$ \\
\hline
\end{tabular}

Source: Act CXVII of 2020 on the Implementation of 2019 Budget of Hungary

Based on Table 2, it is clear that local business tax dominates the Hungarian local tax system, because it covers more than 80 per cent of all local tax revenues. This outstanding ratio makes the Hungarian business tax similar to its German counterpart (die Gewerbesteuer) (Tombor, 2020). Indeed, local business tax surpasses the national 
Gábor Kecsô: Reforms of Local Finance and Taxation in Hungary. Milestones and...

corporate income tax as well. The sum of local business tax was twice and a half the corporate income tax (hereinafter referred as CIT) in 2019. The rate of the CIT is 9 per cent nationally, the rate of the local business tax must not exceed 2 per cent locally. The distinguishing feature between these two fiscal burdens is the tax base, not the tax rate. Local business tax is not a profit (revenue less cost) tax, but rather a revenue tax where a few expenses prescribed by law in a list can be deducted only. This is a good example of that the comparison of tax rates is not sufficient if you intend to compare tax burden. The extent of the tax base is as decisive as the tax rate.

The original closed-list system of local taxation for municipalities till 2015

Local taxes are regulated on two levels. Act C of 1990 on Local Taxes (hereinafter referred as LTA) provides the confines of local taxation that are uniform in the whole country. It is declared in the LTA that one of the ways of establishing fiscal autonomy for local government is the imposition of local taxes. This enables local governments to exercise the autonomous right of local taxation and correspondingly to establish a local tax policy. Decrees of local governments as bylaws may impose local taxes within the confine of LTA. Tax liability derives from the local decree. It means that there is no effective local tax without the decision of the local government's representative body.

What was the essence of the confines laid down in the LTA to 2015? The Hungarian local tax system was built on the closed-list approach (Kecsô, 2016). Municipalities were restricted to choose one or more local taxes listed in the LTA. They did also have the opportunity to select none. Municipalities were not empowered to create a "new" local tax. They could set the tax rate and regulate the exemption or credit of the local $\operatorname{tax}(\mathrm{es})$ imposed by them. These rules are still applicable for the closed-list local taxes which are indicated in Table 2 except municipal tax. Latter one belongs to a special regime discussed later.

There are more common confines in effect that are worth mentioning for the closed-list local taxes. The municipalities' power to levy taxes is limited as follows. In respect of any particular tax category, taxpayers may only be compelled to pay one type of tax as determined by the local government. The rate of the local tax imposed may not be higher than the tax ceiling prescribed by the LTA. The type of tax, the tax rate, exemptions and credits may be governed in such a way to ensure that such taxes must remain consistent with local characteristics, the local government's fiscal needs and the ability to pay of a broad community of taxpayers (LTA Section 7). LTA lays down the legal structure of all closed-list local taxes. These rules mean the "skeleton" for the respective local tax.

Residential and other buildings not used for housing purposes are subject to building tax. This tax liability applies to all rooms and spaces of the building, regardless of their purpose and utilisation. The person subject to building tax liability is the person who is the owner of the building as of the first day of the calendar year. If there is more than one owner, the owners must pay tax in proportion to their respective ownership 
shares in the property. If there is any right registered on the building in the real estate register, the person registered as the holder of such right is subject to tax payment. The basis of the tax, depending on the decision of the local government, is the net floor space of the building expressed in square meters, or the adjusted market value of the building. The maximum rate of tax per annum is $1100 \mathrm{HUF}$ per square meter or 3,6 per cent of the adjusted market price. 1100 HUF can be increased by the annual inflation to keep the real value of the tax rate (LTA Section 11-16).

Land within the area of jurisdiction of a local government is subject to land tax. The person subject to this tax is the owner of the land on the first day of the year. If there is any right registered on the plot in the real estate register, the person registered as the holder of such right must pay this tax. The tax basis, depending on the decision of the local government, is the actual area of the plot expressed in square meters, or the adjusted market value of the parcel. The maximum rate of tax per annum is $200 \mathrm{HUF} / \mathrm{square}$ meter or 3 per cent of the adjusted market value. Inflation correction rule is applicable here as well. It is important that the part of the land on which the building stands, of the same size as the net floor space is exempt from plot tax. This rule avoids double property taxation as to the building and the plot section on which the building is raised (LTA Section 17-22).

The private individuals who could be the taxpayers of the building or plot tax, and the private individuals holding lease rights to a dwelling place owned by a person other than a private individual in the area of jurisdiction of a local government is subject to pay communal tax. The maximum rate of communal tax per annum is 17,000 HUF. In this case, it is very important that taxpayers may only be compelled to pay one type of tax in respect of any particular tax category. So, it is contrary to the LTA if the natural person who is the owner of a building or plot had to pay building tax or plot tax and on the top of that communal tax. Communal tax is alternative to the property taxes. The main differences between the communal tax and the two property taxes are that legal person is out of the scope of the communal tax and the size or value of the property (building, plot) does not affect the sum of communal tax (LTA Section 23-26).

A private individual who is not a permanent resident, spending at least one guestnight within the area of jurisdiction of a local government is subject to tourism tax liability. The tax base is, depending on the decision of the local government, the number of the guest-nights or the accommodation fee or in absence of such any consideration payable for the accommodation in any form. The maximum rate of tax is $300 \mathrm{HUF}$ plus inflation per person or 4 per cent of the accommodation fee (LTA Section 30-34).

All business activities pursued permanently or temporarily in the area of jurisdiction of a local government is subject to local business taxation. The taxable person is the entrepreneur. Taxable business activity means any for-profit or non-profit activity of an entrepreneur performed in that capacity. An entrepreneur whose seat or place of business is located in the area of jurisdiction of a local government is regarded as conducting permanent business activities, regardless of whether any or all of his op- 
erations are conducted outside his seat. Business activities are regarded temporary if, in the area of jurisdiction of a local government, an entrepreneur without a seat or place of business registered in such area is engaged in: a) construction, or exploring or surveying natural resources, if the duration of the activities performed continuously or with interruption exceeds thirty days and does not reach one hundred and eighty-one days within the same tax year; b) any activity, other than what is contained in the previous point, if it directly results in income, provided that the entrepreneur does not have a seat or place of business registered in the area of jurisdiction of any local government.

In the case of business activities pursued on a permanent basis, the tax base is the net sales revenue, less:

a) the sum of costs of goods sold and the value of intermediated services sold

b) fees paid to subcontractors;

c) cost of raw materials and consumables;

d) the direct costs of basic research, applied research and experimental development.

For temporary business activities the tax must be established on the basis of the number of calendar days during which the activity was performed. Any fraction of a day in which activities are performed must be considered a full calendar day. For permanent business activities the maximum rate of tax per annum is 2 per cent. For temporary business activities the tax rate may not exceed HUF 5,000 per calendar day (LTA Section 35-40).

It has to be noted, that the four above mentioned deductible costs were implemented through lots of amendments between 1993 and 2010. In its original concept, local business tax on permanent business activity was a pure revenue tax which tax base covered the sales revenue in the fiscal year without the inclusion of value added tax. Latter characteristic explains the "net" phrase in the tax base (Kecsó, 2020). It cannot be overemphasised that local business tax is still a revenue tax for entrepreneurs whose costs are over the scope of the above mentioned points. For example, costs of wages, services consumed, depreciation and of amortisation are non-deductible.

The Hungarian Government revealed the newest measures in the stimulus package that aims at boosting the economy and protecting the workplaces. ${ }^{11}$ One of these provisions is about decreasing the rate of the local business tax by 50 per cent for self-entrepreneurs and for small and medium-sized businesses in the whole country. The reasoning is that those taxpayers are in the most vulnerable position and they need all governmental support to keep their liquidity and solvency. Approximately half of the employment is provided by this sector and it produces substantial part of GDP. Multinational enterprises do not benefit from this measure. While this tax cut is in accordance with the contra-cyclical tax policy balanced budget for local governments should be granted too. Intergovernmental grants will replace the drop in the sum of local business tax. The rules of the allocation of those grants are to be presented soon. 
Civic Review · Vol. 16, Special Issue, 2020

The open list approach from 2015

Open list approach of local taxation allows local governments to impose any taxes that comply with a few general provisions laid down upper-level legal sources (e.g. constitution or statute). In this case, local governments are free to "invent" new local taxes. They are not restricted to impose listed local taxes (Kecsó, 2016). An amendment to the LTA reformed the Hungarian local tax system as of the 1st of January 2015. The original closed-list stays alive, but it has been supplemented by new taxing power. The local government may, within its area of jurisdiction, impose one or more municipal $\operatorname{tax}(\mathrm{es})$ by decree, which are not prohibited by any other act. The local government may levy municipal tax on any basis of assessment, provided that it is not covered by mandatory public duties of any kind. Municipal tax may not be imposed on the state, any local governments, any organisations, or on any entrepreneurs (LTA Section 1/A).

What are the general conditions to comply with? Firstly, the potential taxpayer is limited. All legal persons (organisations) are excluded. The subject of the municipal tax can only be natural person in the status of consumer. If a natural person is a selfentrepreneur, he/she cannot be subject to tax with respect to his/her business activity, but he or she can with respect to his or her non-business activity. This condition is important from the aspect of the competitions of undertakings. Municipal tax is designed not to abuse the level playing field. This tax does not affect the undertakings. Secondly, its possible tax base is limited. The object of the municipal tax can only be what is not under the scope of any other fiscal levy. The aim of this rule is to avoid intra-national (domestic) double taxation. For instance, a municipal tax on private individuals' income cannot be imposed, because there is a national tax on personal income.

In practice, most common municipal tax is the tax on agricultural land. So far not more than 200 municipalities have introduced this tax which typically a property tax levied on arable land owned by private individual who does not perform farming activity over his/her land. If he/she does so, it is forbidden to be taxed, because he/ she is a self-entrepreneur. Extraordinary examples of municipal tax from the practice are the tax on pony and on tower.

In my view, the municipal tax is a very important arrangement theoretically, because it widens the fiscal autonomy of municipalities, but it is less interesting from the point of view of the reality. Most of the possible tax base is covered by other fiscal levies, consequently mission almost impossible to find a free and suitable object to tax. In addition, municipal tax provides very small amount of revenue (see Table 2). These two reasons are strongly interrelated. That is why I believe the Hungarian municipal tax is like the German petty taxes (die kleinen Gemeindesteuern) (Tombor, 2020).

The counties' power to tax from 2020

Hungarian counties did not have power to tax from 1990 till summer 2020. COVID legislation made counties possible to impose any local taxes from the closed-list. Counties did not gain power to introduce municipal taxes. Counties' local taxation is restricted to 


\section{Gábor Kecsố: Reforms of Local Finance and Taxation in Hungary. Milestones and...}

and connected to the so-called special investment zone. The Government can declare by decree a territory of one or more municipalities partly or fully as special investment zone, if the economic activity within that area is very significant and has a decisive effect on the county's economy (Act LIX of 2020). The establishment of a special investment zone has many legal consequences. Taxing power is one of those. The county gets right to impose taxes in this special area and if does so the county tax replaces the respective tax of the municipality or municipalities. If a local government where the special investment zone is located levied a local tax, the county government should not increase the burden of taxpayers during the fiscal year. The decree of the local government where the special economic zone is located on local taxes apply until the county government adopts a decree relating to local taxes, not exceeding 120 days after the date of entry into force of the Government decree on the establishment of the given special investment zone (LTA Section 42/G). One special investment zone has been established so far. This is situated in the area of Göd (Government Decree 294 of 2020).

\section{CONGLUSIONS}

Crises bring changes. This happened in Hungary around 1995 during the budget crisis, around 2010 when the US stock market crash made turmoil in the real economy and just recently when COVID-19 quarantines the whole world. How has local finance been evolved through these three decades? Within the scope of this paper, one can argue that many models of local taxation and of confining local borrowing were applied. In 1990 only municipalities had power to impose local taxes according to the concept of the closed-list approach. At the moment counties can levy local taxes in the area of special investment zone, and further municipalities have the right to introduce municipal tax in accordance with the open list version of local taxation. In 1990 local governments' borrowing were disciplined by the market. Lately their borrowing is under the active control of the Government. Tax sharing has been eroded. What is constant is the dominance of the local business tax and the fact that changes will never end. For example, the hottest topic now is to halves the rate of the local business tax nationally for self-entrepreneurs and for small and medium-sized businesses.

\section{Notes}

1 The special legal status of Budapest (dual self-government system) is out of the scope of this paper.

2 Local autonomy means relative independence from the central government, own policy making capacities in certain fields and from legal point of view particular or sub-legal order within the absolute legal order of the state according to the Kelsen's definition (Kelsen, 1946).

3 These rights were introduced by an amendment in 1990 to the former constitution of Hungary as follows: Article 44/A. (1) The local representative body a) shall independently manage and administer the affairs of local government and its decisions may only be reviewed with respect to their legality; b) shall exercise the rights of ownership in the assets of local government, and independently manage local government revenues, and may undertake business activities at its own liability; c) shall be entitled to its own revenues for attending to the duties of local government as prescribed by law, and shall furthermore be entitled to state support commensurate to the scope of such duties; d) shall determine the types 
Civic Review · Vol. 16, Special Issue, 2020

and rates of local taxes in accordance with the framework established by law; e) shall independently establish its own organisation and rules of procedure in accordance with the framework established by law; f) may develop symbols and emblems of government, and establish local honors and titles; g) may present proposals to the authorities responsible for decisions that affect the local population; $h$ ) may freely merge with other local representative bodies and create associations of local government for the representation of their interests, may co-operate with the local governments of other countries and may be a member of international associations of local government. (2) Local representative bodies may issue decrees, which may not be contradictory to other legal acts.

4 Five main models of confining local borrowing can be distinguished based on international comparison. 1) market discipline or a reliance model 2) co-operative approach 3) rules-based approach or passive control 4) administrative approach or active control 5) direct democracy model (Ter-Minassian and Craig, 1997; Dafflon, 2008).

5 The rules were the followings: LGA 1990 Section 88. (2) The amount of liabilities arising from the commitments assumed by a local self-government for the year (loans and loan costs, bond issues, guarantees and sureties, leasing) may not exceed the local self-government's adjusted current revenues. (3) "Adjusted current revenue" shall mean 70 per cent of the current revenues estimated for the year less short-term liabilities (principal and interest payments, leasing charges) paid for the year. (4) The limits referred to in Subsections (2) and (3) shall not apply to liquid credit. (5) For the purposes of this Section, "current revenue" shall mean local taxes, duty revenue, interest income, environmental fines, and other special income of the local self-government. (6) For the purposes of this Section "short-term liability" shall mean loans and credit received for a term of one year or less and the instalment payments on longer-term obligations that fall due during the year, not including the liabilities guaranteed by the Government. (7) For the purposes of this Section, "liquid credit" shall mean any loan that is borrowed for financing public services and state administration services and repaid in the same year.

6 See soft and strict budget constraint: (Kornai, 1986; Oates, 2006).

This was laid down in the LGA 1990 Section 90 (2).

8 The full text of the Article 32 (1) of the Fundamental Law is the following: (1) Within the frameworks of statute, in the administration of local affairs, the local government: a) shall issue decrees; b) shall make decisions; c) shall administrate independently; d) shall establish its own organisation and rules of procedure independently; e) shall exercise the rights of ownership regarding the property of the local government; f) shall establish its budget and, based on that, shall manage local government revenues independently. g) may undertake entrepreneurial activities with the financial resources and income that can be used for this purpose, without endangering the performance of obligatory tasks; $h$ ) shall decide on the types and rates of local taxes; i) may create symbols and emblems of the local government, and establish local honours and titles; $\mathrm{j}$ ) may request information from the authorised and competent organ, initiate decision-making and express its opinion; k) may freely associate with other local representative bodies, may create local government associations for the representation of their interests, may co-operate with the local governments of other countries in its sphere of authority and competence, and may be a member of international organisations of local governments; 1) perform further tasks and competences defined by statute. Furthermore Article 32 (2) 1 of the Fundamental Law states that while performing its tasks the local government shall issue decrees either in order to regulate local social affairs not regulated by statute, or upon the authorisation of a statute.

9 The conditions to the approval are the following. 1) local loan does not risk debt target envisaged in the act on central budget 2) local loan is taken out for investment purpose attached to mandatory local functions and the maintenance of the new or renovated property is provided in the long run 3) debt serviceto-own revenues ratio is not more than $50 \%$ ) local government introduced at least one local tax out of the four qualified local taxes such as local business tax, building tax, land tax and communal tax. It should be noted that there are more local taxes in Hungary, but their imposition is not adequate for approval.

10 The source of the data is the acts on the implementation of the 2010 and 2014 budgets of Hungary.

11 As the relevant Government Decree will be promulgated after the submission of this paper, no details may be given here. The date of the entry into force will probably be the 1st of January 2021. 
Gábor Kecsô: Reforms of Local Finance and Taxation in Hungary. Milestones and...

\section{REFERENGES}

Council of Europe (2006): A European Definition of Shared Taxes. www.oecd.org/ctp/federalism/36444032. pdf

Csûrös, G. (2006): A helyi önkormányzatok és az alkotmány a pénzügyi jog aspektusából [Local governments and constitution from the aspect of the fiscal law]. Debreceni Jogi Mühely, Vol. 3, No. 2, 1-16.

Dafflon, B. (2002): The Requirement of a Balanced Budget and Borrowing Limits in Local Public Finance. Setting out the Problems. In: Dafflon, B. (ed.): Local Public Finance in Europe. Balancing the Budget and Controlling Debt. Edward Elgar Publishing, Cheltenham.

Dafflon, B. (2008): The Assignment of Functions to Decentralised Government: from Theory to Practice. In: Ahmad, E. and Brosio, G. (eds.): Handbook of Fiscal Federalism. Edward Elgar Publishing, Cheltenham, 283-298.

Gellén, M. (2014): From Overdecentralisation to Overcentralisation? Hungarian Experience in Handling the Crisis at the Local Level. NISPAcee Journal of Public Administration and Policy, Vol. 7, No. 2, https:// doi.org/10.2478/nispa-2014-0003.

HCSO (2019): Magyarország közigazgatási helynévkönyve [Gazetteer of Hungary]. Hungarian Central Statistical Office, Budapest.

Kecsô, G. (2016): A helyi önkormányzatok pénzügyi jogi jogállása: a jogállást meghatározó jogintézmények modelljei a bevételi oldalon: Anglia - USA - Magyarország [Fiscal law status of local governments. Models of legal arrangements determining the status as to the budgetary revenues]. ELTE-Eötvös, Budapest, https:// doi.org/10.15476/ELTE.2015.078.

Kecsô, G. (2020): A magyar helyi iparúzési adó [The Hungarian local business tax]. In: A helyi adók szabályozása és joggyakorlata Magyarországon külföldi kitekintéssel - különös figyelemmel az iparúzési adóra és a helyi vagyonadók arányosságára [The legislation and jurisprudence of local taxes in Hungary with international outlook - focusing on the local business tax and the proportionality of the local wealth taxes]. University of Public Service, Budapest, 35-53.

Kelsen, H. (1946): General Theory of Law and State. Harvard University Press, Cambridge, MA.

Kornai, J. (1986): The Soft Budget Constraint. Kyklos, Vol. 39, No. 1, https://doi.org/10.1111/j.1467-6435. 1986.tb01252.x.

Kulcsár, K. (1997): Politikai rendszer és politikai kultúra [Political system and political culture]. In: Glatz, F. (ed.): A demokrácia intézményrendszere Magyarországon [The system of the institution of democracy in Hungary]. MTA, Budapest, 11-31.

Lentner, Cs. (2014): The Debt Consolidation of Hungarian Local Governments. Public Finance Quarterly, Vol. 59, No. 3, 310-325.

Lentner, Cs. (2020): East of Europe, West of Asia. L'Harmattan, Budapest.

Oates, W. E. (2006): On the Theory and Practice of Fiscal Decentralisation. IFIR Working Paper, 2006-05.

Patyi, A. (2015): Local Governments. In: Varga, Zs. A. et al. (eds.): The Basic (Fundamental) Law of Hungary. A Commentary of the New Hungarian Constitution. Clarus, Dublin, 259-276.

Ter-Minassian, T. and Craig, J. (1997): Control of Subnational Government Borrowing. In: Ter-Minassian, T. (ed.): Fiscal Federalism in Theory and Practice. IMF, Washington, 156-172.

Tombor, Cs. (2020): A helyi adórendszer Németországban [The local tax system in Germany]. In: A helyi adók szabályozása és joggyakorlata Magyarországon külföldi kitekintéssel - különös figyelemmel az iparúzési adóra és a helyi vagyonadók arányosságára [The legislation and jurisprudence of local taxes in Hungary with an international outlook - and with focus on the local business tax and the proportionality of the local wealth taxes]. University of Public Service, Budapest, 93-142.

Verebélyi, I. (1987): A tanácsi önkormányzat [The council as local government]. KJK, Budapest. 